\title{
Effect of Soil Flexibility on Seismic Performance of 3-D Frames
}

\author{
Ayman Ismail ${ }^{1}$ \\ ${ }^{1}$ (Steel and structure, Housing and Building National Research Center, Cairo, Egypt.)
}

\begin{abstract}
In most of the designs of rigid structural frames, the analysis is carried out by assuming fixity at base, which means that the building is idealized to rest on hard rock. This paper discusses the importance of considering the effect of soil stiffness on the seismic performance of rigid structural frame system resting on it. Flexibility of soil causes lengthening of lateral natural period of the structural system due to overall decrease in lateral stiffness. Such lengthening of lateral natural period may considerably alter the seismic response of the building frames resting on isolated footings. Hence, focus of this paper is to bring out the effect of flexible foundation soil on the performance of $2 D$ and $3 D$ frame-foundation systems and their overall dynamic behavior from pushover analysis, a static non-linear analysis. Gazetas [1] model is used for representing stiffness of soil and the foundation resting on it as a spring. For analysis, design and pushover analysis of frame SAP2000 v15 [2] software is used. It is observed that modulus of soil has considerable effect on natural period of system and overall performance of structural system, indicating that idealization of fixity at the base may be seriously erroneous.
\end{abstract}

Keywords: Natural frequency; seismic force; soil flexibility; soil-structure interaction; SAP2000; inelastic behavior; pushover analysis.

\section{Introduction}

In most seismic building codes, the role of the soil structure interaction is usually considered beneficial to the structural system under seismic loading since it lengthens the lateral fundamental period and leads to higher damping of the system. This conclusion could be misleading. Recent case studies and post-seismic observations suggest that the soil structure interaction can be detrimental and neglecting its influence could lead to unsafe design for both the superstructure and the foundation especially for structures founded on soft soil, Mylonakis and Gazetas, [3], Stewart et al. [4,5], Mylonakis and Gazetas,[6], Boris et al [7], Khalil et al. [8] and Gullu and Pala [9]. They established that the seismic response of a Single-Degree of Freedom (SDOF) structure with a surface foundation can be predicted by an equivalent fixed-base SDOF with modified period.

The accelerations that occur in the rock layer during an earthquake get transmitted to the building through the soil resting on rock layer. When the soil is relatively soft and layered, the accelerations tend to get magnified, resulting in the structure attracting higher seismic loads. This must be taken into account during structural design. Knowledge of the soil strata is equally essential for designing the foundations of the building. Buildings located on loose granular soils, in the presence of subsoil water, have another serious and potential danger that can occur during an earthquake. The soil can behave like quicksand through the phenomenon of liquefaction. This happens because of a sudden increase in pore water pressure on account of seismic shear waves, causing the water-sand mixture to flow upwards and practically convert the effective stress to vanish.

The load and deformation characteristics of the structural and geotechnical components of the foundations of structures can affect, and in some cases dominate, seismic response and performance. The common design practice for dynamic loading assumes the building frames to be fixed at their bases.

Most of the designs consider the structure to rest on hard soil and fixity is idealized at the ground level. Accordingly, ECP201 [10] provides an empirical equation to evaluate the natural period of bare frames as follows.

$\mathrm{T}_{\mathrm{a}}=0,075 \mathrm{~h}^{0.75}$

Where Ta is the natural period in seconds and $\mathrm{h}$ is the height of frame in meters.

On the other hand, some designers assume pinned joint for the connection between columns and foundations to reduce transferring of bending stresses from superstructure to foundations. In reality, supporting soil medium allows movement to some extent due to its natural ability to deform. This may affect the overall stiffness of the structural system and hence, may increase or decrease the natural periods of the system. Such influence of partial fixity of structures at the foundation level due to soil flexibility results in either unnecessarily costly or unsafe design. Thus, the interaction between the structure and the soil needs to be modelled accurately in order to design earthquake resistant structures correctly.

Recognizing this important fact, many structural engineers have included representations of foundation strength and stiffness in their seismic analysis models for many years. 
Desai et al. [11] presented a finite element procedure for the general problem of three-dimensional soilstructure interaction involving nonlinearities caused by material behavior, geometrical changes, and interface behavior. The formulation is based on the updated LaGrange or approximate Eulerian approach with appropriate provision for constitutive laws.

Aljanabi et al. [12] studied the interaction behaviour of plane frames with an elastic foundation of the Winkler's type, having normal and shear moduli of subgrade reactions. An exact stiffness matrix for a beam element on an elastic foundation having only a normal modulus of sub-grade reaction was modified to include the shear modulus of sub-grade reaction of the foundation as well as the axial force in the beam. The results indicated that bending moments might be considerably affected according to the type of frame and loading.

Mandal et al. [13] presented a computational iterative scheme for studying the effect of soil-structure interaction on axial force and column moments. The results obtained from the computational scheme were validated from experimental study. A small-scale two storey two-bay frame was analyzed. The frame was placed on a kaolin bed with adequate arrangement of drainage. The proposed computational scheme could be used to predict the increase in axial force and moments in structural members due to the effect of soil structure interaction.

Al-Shamrani and Al-Mashary[14] presented a simplified procedure for the analysis of soil-structure interaction behavior of two-dimensional skeletal steel or reinforced concrete frame structures resting on isolated footings that are supported by different types of soil. The main program was made of two major modules; one for soil settlement calculations and another for the analysis of structure. They evaluated the effect of interaction on the predicted settlements, footing loads, and internal bending moments of the structural members.

The effect of soil-structure interaction on the change in lateral natural periods of building frames resting on isolated and grid foundations has been observed by Bhattacharya et al. [15]. Variation of a number of factors such as (a) different soil conditions, (b) number of stories, (c) number of bays, (d) the ratio of flexural stiffness of columns to that of beams and (e) frequency of the ground excitation has been considered.

Thangaraj and Ilamparuthi[16] compared interaction and non-interaction analyses for the space frameraft foundation-soil system using ANSYS finite element code. The soil was treated as an isotropic, homogenous and elastic half space medium. A detailed parametric study was conducted by varying the soil and raft stiffness for a constant building stiffness.

Agrawal and Hora [17] studied the interaction effect of frame, isolated footing and soil media under seismic loading. Various analyses were performed on frame-footing-soil system by considering plane frame, infill frame, homogeneous soil and layered soil mass. The frame was considered to act in linear elastic manner while the soil mass to act as nonlinear elastic manner. They concluded that the shear forces and bending moments in the superstructure get significantly altered due to differential settlements of the soil mass.

Chinmayi H.K. et al. [18] focused on Soil Structure Interaction (SSI) analysis of a symmetric 16 storey $\mathrm{RC}$ frame shear wall building over raft foundation subjected to seismic loading. Four types of soils based on shear wave velocity were considered. Responses in terms of variation in natural period, base shear and deflection obtained from the analysis of the SSI model were compared with that obtained from conventional method assuming rigidity at the base of the structure.

The major factor for structural failure is the wrong foundation treatment. Foundation is a part of the superstructure which transfers the loads coming to the superstructure along with the self-weight of the structure to the soil, on which it rests, without overstressing the soil. Overstressing the soil can result in either excessive settlement or shear failure of the soil, both of which cause damage to the structure.

\section{Spring coefficients for soil flexibility}

A complete set of algebraic formulae and dimensionless charts for readily computing the dynamic stiffness and damping coefficient of foundations harmonically oscillating on/in a homogeneous half-space is available by Gazetas [1]. Table 1 presents the surface stiffness of rigid plate in different degrees of freedom.

Table 1 : Expressions for stiffness of equivalent springs along various degrees of freedom

\begin{tabular}{|l|l|}
\hline Degrees of freedom & Stiffness of equivalent soil spring \\
\hline Vertical & {$[2 \mathrm{GL} /(1-v)]\left(0.73+1.54 \chi^{0.75}\right)$ with $\chi=\mathrm{A}_{\mathrm{b}} / 4 \mathrm{~L}^{2}$} \\
\hline Horizontal (lateral direction) & {$[2 \mathrm{GL} /(2-\mathrm{v})]\left(2+2.5 \chi^{0.85}\right)$ with $\chi=\mathrm{A}_{\mathrm{b}} / 4 \mathrm{~L}^{2}$} \\
\hline Horizontal (longitudinal direction) & {$[2 \mathrm{GL} /(2-\mathrm{v})]\left(2+2.5 \chi^{0.85}\right)-[0.2 /(0.75-\mathrm{v})] \mathrm{GL}[1-(\mathrm{B} / \mathrm{L})]$} \\
\hline Rocking (about the longitudinal) & {$[\mathrm{G} /(1-v)] \mathrm{I}_{\mathrm{bx}}^{0.75}(\mathrm{~L} / \mathrm{B})^{0.25}[2.4+0.5(\mathrm{~B} / \mathrm{L})]$} \\
\hline Rocking (about the lateral) & {$[3 \mathrm{G} /(1-v)] \mathrm{I}_{\mathrm{by}}^{0.75}(\mathrm{~L} / \mathrm{B})^{0.15}$} \\
\hline Torsion & $3.5 \mathrm{GI}_{\mathrm{bz}}^{0.75}(\mathrm{~B} / \mathrm{L})^{0.4}\left(\mathrm{I}_{\mathrm{bz}} / \mathrm{B}^{4}\right)^{0.2}$ \\
\hline
\end{tabular}

Note: $\mathrm{A}_{\mathrm{b}}$-Area of the foundation considered; B and L-half width and half-length of a rectangular foundation, respectively; $\mathrm{I}_{\mathrm{bx}}$; $\mathrm{I}_{\mathrm{by}}$; andI $\mathrm{I}_{\mathrm{bz}}-$ Moment of inertia of the foundation area with respect to longitudinal, lateral and vertical axes, respectively. 


\section{Pushover Analysis}

Pushover analysis is a static non-linear procedure in which the magnitude of the lateral load is incrementally increased maintaining a predefined distribution pattern along the height of the building. With the increase in the magnitude of loads, weak links and failure modes of the building can be found. Pushover analysis can determine the behaviour of a building, including the ultimate load it can carry and the maximum inelastic deflection it undergoes. Local nonlinear effects are modelled and the structure is pushed until a collapse mechanism is developed. At each step, Base shear and pushover curve are developed. The graphs are plotted with base shear along the vertical axis and roof displacement along the horizontal axis. Figure 1 presents the generalized pushover curve consisting of spectral acceleration along vertical axis and spectral displacement along horizontal axis. It has two components namely, capacity curve and demand curve. Capacity curve represents the capacity of a structural system in terms of base shear and roof displacement. Demand curve represents the demand under a given seismic force for known damping and soil conditions. Here, the capacity curve is represented by A, B, C, D and E which suggests different stages in a building studied under increased horizontal earthquake force. Based on structural and functional requirements, three different demarcations are represented, namely, Immediate Occupancy (IO), Life Safety (LS) and Collapse Prevention (CP). Accordingly, the following are the four levels a structure can experience in terms of increase in vulnerability. They are Operational level, Damage control level, Limited Safety level and Hazard level. Normally, the structure experiences elastic linear deformation from A to B beyond which the increase in load carrying capacity is nonlinear and ultimate load is reached at C. At this stage, there will be a drop in the load carrying capacity and every structure has minimum strength called residual strength to which it will settle. Pushover analysis will indicate to what state the given structure reaches under assigned load, it is represented by pushover hinges of different stages. Further, the point of intersection between capacity curve and demand curve is called the performance point whose co-ordinates provide information about the seismic performance of a given structure under a design earthquake load.

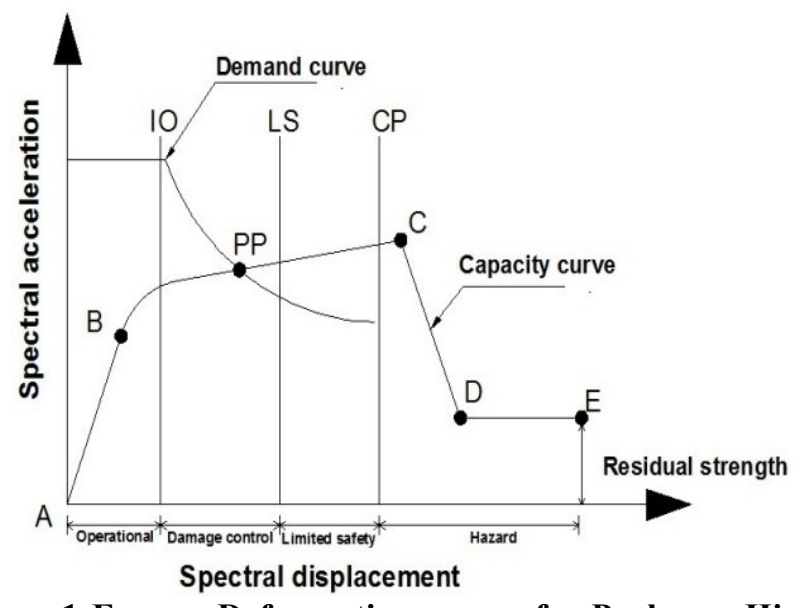

Figure 1:Force - Deformation curves for Pushover Hinges

\section{Present Analysis}

To study the effect of soil flexibility on response of structural frame system with 3D idealizations, stiffness of soil was considered along with assuming fixity at the base for two types of building foundations. First, a three stories single bay reinforced concrete frame with isolated footings. Below the center of gravity of the each foundation, three translational springs together with two rotational springs about mutually perpendicular global axes are assigned to simulate the effect of soil flexibility. Second building is constructed as a space building with 5 stories resting on mat foundation with depth $0.60 \mathrm{~m}$. Sap2000, finite element software was used for analysis, design and generation of pushover curves of reinforced concrete frame system. Further, to understand the effects of 3D idealizations on structural frame system, comparison is made for both frame systems resting on ground of varying soil moduli. Figure 2 gives the details about the RC frame considered in the present study. The structure comprises of single bay three storey with an $8 \mathrm{~m}$ in X direction, $8 \mathrm{~m}$ in $\mathrm{Y}$ direction and a floor height of $3 \mathrm{~m}$. The foundation was idealized as rigid providing fixity at base to represent rigid base and Gazetas (1991) model was used to represent soil stiffness depending on the soil modulus, flexibility of the base was idealized. Table 2 provides the design details of beams, columns and footings. 


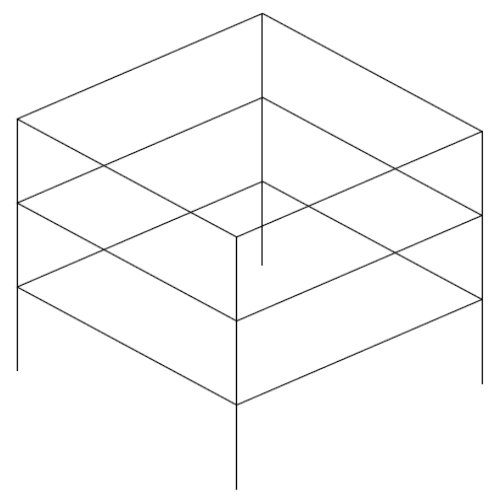

Figure 2: Structural frame systems 3D model

Table 2 Design details of components of frame

\begin{tabular}{|c|c|c|c|c|c|}
\hline & Component & $\begin{array}{c}\text { Size } \\
(\mathbf{m m})\end{array}$ & $\begin{array}{c}\text { Steel } \\
\text { Grade }\end{array}$ & $\begin{array}{c}\text { Concrete } \\
\text { Grade }\end{array}$ & Rft. ratio(\%) \\
\hline 1 & columns & $\mathbf{3 0 0 \times 6 0 0}$ & Fy360 & M25 & 2.2 \\
\hline 2 & beams & $\mathbf{3 0 0 \times 7 5 0}$ & Fy360 & M25 & 2.2 \\
\hline 3 & footing & $\mathbf{3 0 0 0 \times 4 0 0 0 \times 5 0 0}$ & Fy360 & M25 & 1.5 \\
\hline
\end{tabular}

Second building is a reinforced concrete frame building with multi bays in X-direction or Y-direction. Egyptian Loading Code (ECP201-2012) states that the design horizontal acceleration as $0.15 \mathrm{~g}$ for this building zone. The footings of the five storey building are located on soil layer, which can be classified as class type "C" according to the Egyptian loading code. Note that, a seismic load reduction factor of 5.0 is taken into account as mostly done in practice for this type of RC frame structures. A typical floor plan of the building, which is used for housing purposes, is given in Figure 3. According to Figure 3, it can be seen that all columns are rectangular. Characteristic compressive strength of concrete is taken as $25 \mathrm{MPa}$. Both longitudinal and transverse reinforcement are deformed bars with characteristic yield strength of $360 \mathrm{MPa}$. The columns schedules of the building are shown in Figure 4. The longitudinal reinforcement of the building, consist of $16 \mathrm{~mm}$ or $12 \mathrm{~mm}$ bars at $150 \mathrm{~mm}$ spacing as shown in Figure 4 . All beams with dimensions $25 \times 70 \mathrm{~cm}$ and were reinforced with $4 \mathrm{Y} 16$ as bottom reinforcement and 4 Y 16 as top reinforcement over columns.

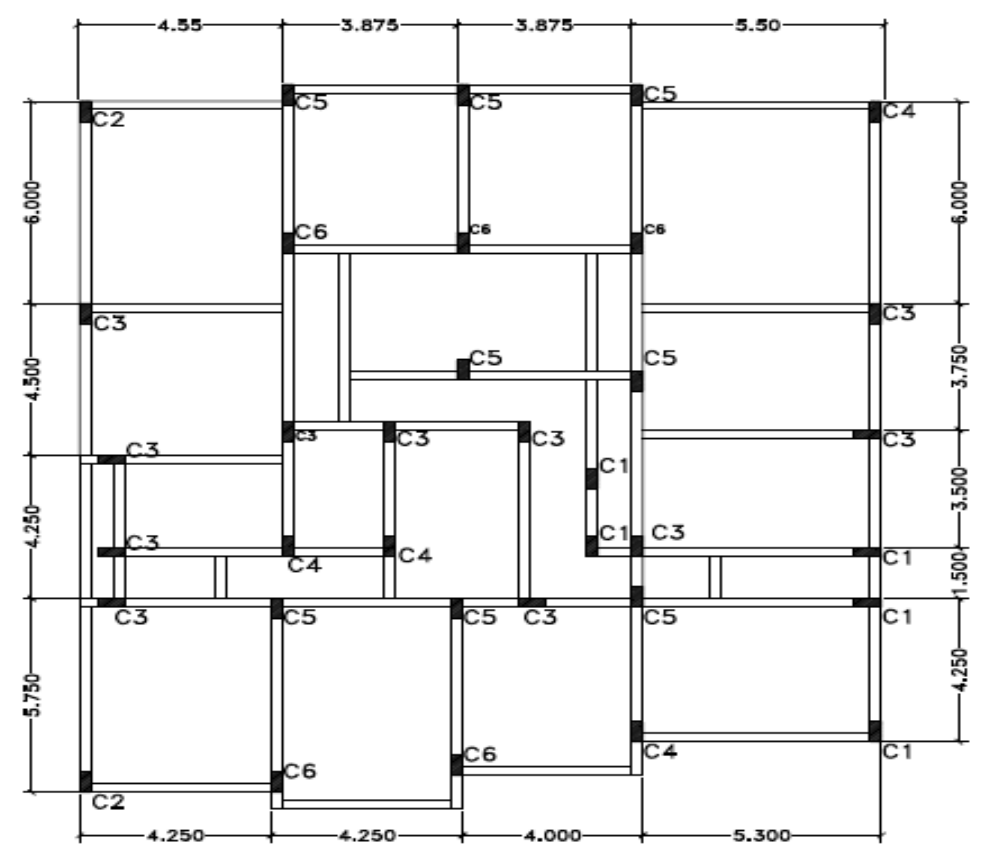

Figure 3:Typical floor plan of the building 


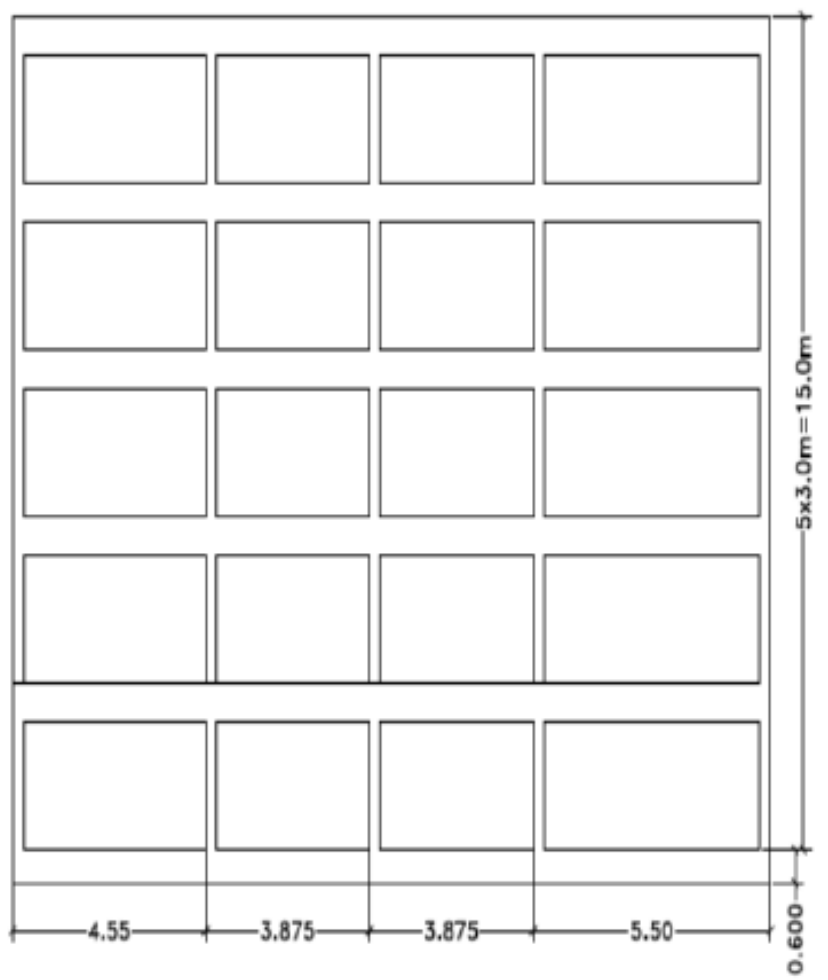

\begin{tabular}{|l|c|c|c|}
\hline \multicolumn{2}{|c|}{ model } & Bas. + Gr. & $\begin{array}{c}1^{\text {st }}+ \\
2^{\text {nd }}+3^{\text {rd }} .\end{array}$ \\
\hline \multirow{2}{*}{ C1 } & Dim. & $25 \times 50$ & $25 \times 40$ \\
\cline { 2 - 4 } & Rft. & $8 \phi 16$ & $8 \phi 16$ \\
\hline \multirow{2}{*}{ C2 } & Dim. & $25 \times 55$ & $25 \times 45$ \\
\cline { 2 - 4 } & Rft. & $8 \phi 16$ & $8 \phi 16$ \\
\hline \multirow{2}{*}{ C3 } & Dim. & $25 \times 60$ & $25 \times 50$ \\
\cline { 2 - 4 } & Rft. & $8 \phi 16$ & $8 \phi 16$ \\
\hline \multirow{2}{*}{ C4 } & Dim. & $25 \times 65$ & $25 \times 65$ \\
\cline { 2 - 4 } & Rft. & $8 \phi 16$ & $8 \phi 16$ \\
\hline \multirow{2}{*}{ C5 } & Dim. & $25 \times 70$ & $25 \times 60$ \\
\cline { 2 - 4 } & Rft. & $10 \phi 16$ & $8 \phi 16$ \\
\hline \multirow{2}{*}{ C6 } & Dim. & $25 \times 90$ & $25 \times 80$ \\
\cline { 2 - 4 } & Rft. & $12 \phi 16$ & $10 \phi 16$ \\
\hline
\end{tabular}

Figure 4: Typical frame \& Columns schedule

\section{Results And Discussion}

\subsection{Simple Building with one bay in $\mathrm{X}, \mathrm{Y}$ direction with isolated footings}

Figure 5 represents the result of 3D frame system with seismic force in $\mathrm{X}$ direction for six different idealization namely fixed base, pinned base, base with soil modulus of $1000 \mathrm{MPa}, 100 \mathrm{MPa}, 10 \mathrm{MPa}$ and 1 $\mathrm{MPa}$. The base shear is plotted along vertical axis and roof displacement along horizontal axis. It can be seen that, for the case in which the soil modulus is $(\mathrm{Q}=1 \mathrm{MPa})$, roof displacement increases linearly with increase in base shear up to around $320 \mathrm{KN}$ and the structure will not take any further load. This is because the soil is very soft and any earthquake load beyond this limit cannot be transferred to the structure. In other words, soil experiences failure. In the case of structure on soil with $\mathrm{Q}=10 \mathrm{MPa}$, it can be clearly seen that the base shear carrying capacity up to $550 \mathrm{KN}$ is observed. Beyond a roof displacement of $0.1 \mathrm{~m}$, the structure tends to collapse. Further, structure on very stiff soil $(\mathrm{Q}=100 \mathrm{MPa})$ and with rigid base show similar pattern of pushover curve with higher base shear carrying capacity. However, it appears that the ductility features are slightly reduced.

Considering the importance of evaluating the natural period of system, Figure 6 presents the effect of soil stiffness on the natural period of frame system. For this purpose, Eigen value analysis is carried out using Sap2000 to estimate the fundamental natural period under different situations, for 3D idealizations. It can be seen that the fundamental natural period of the system is large when frame rests on very soft soil. From these results, it is equally important to estimate the fundamental natural period of frame system as near resonance conditions have resulted in several failures during the past earthquakes.

\subsection{Typical building with multi bays in $\mathrm{X}, \mathrm{Y}$ direction with mat foundation}

The change in fundamental lateral natural period due to the effect of soil-structure interaction is studied on 5 storey building with raft foundation resting on layered soil with variable values of bearing capacity. For horizontal X-direction, results of natural frequencies are shown in Figure 7. Figure 8 shows the natural frequencies of the building for Y-direction versus different type of soil represented by bearing capacity values. It is obvious that, increasing the bearing capacity will increase the natural frequency of the building till the bearing capacity gives the effect of fixed base in case of very stiff soil. For the building frame resting on very soft clay, a maximum increase of more than three times is observed either in X direction or Y-direction. Also, it is observed that this increase, in general, gradually decreases with the increase of soil hardness. The empirical formula for prediction of fundamental natural frequency of the building gives small values than that calculated using mathematical Eigen value for all types of soil. This indicates that, the applied seismic base shear can be modified by increasing empirical natural frequency values by about 20\% as mentioned in ECP201-(2012). 


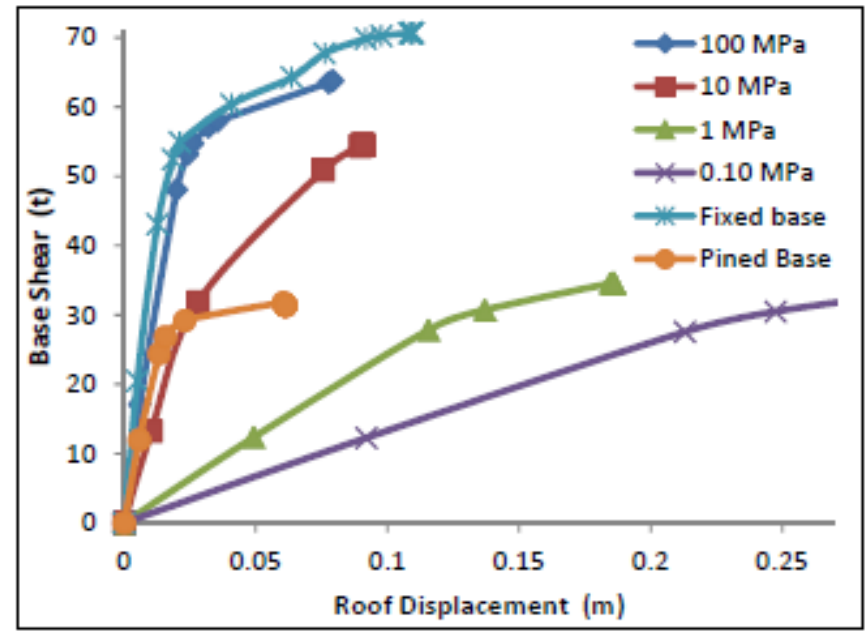

Figure 5: Pushover curves for 3D frame system with seismic force in $X$ direction on grounds of varying soil moduli

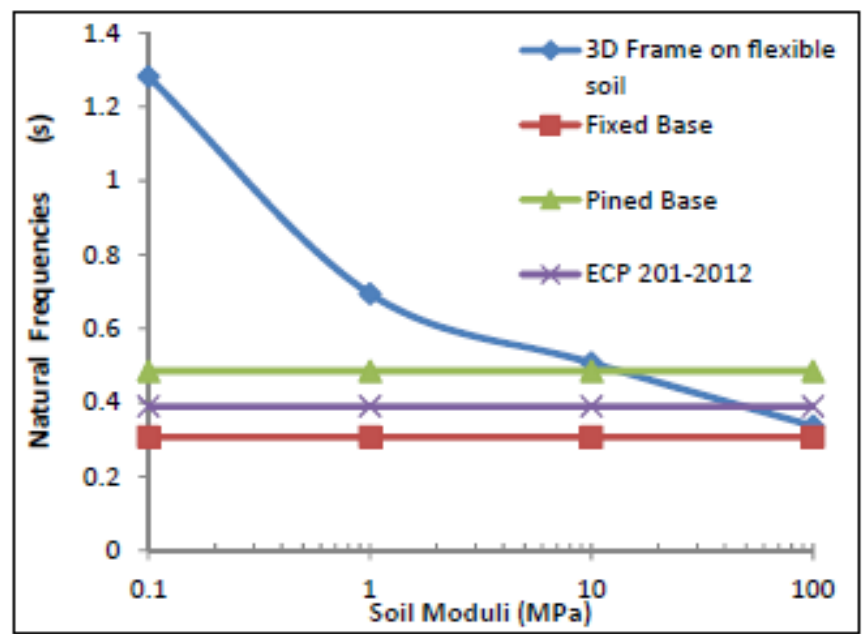

Figure 6:Influence of soil modulus on fundamental natural period of frame system by different approaches

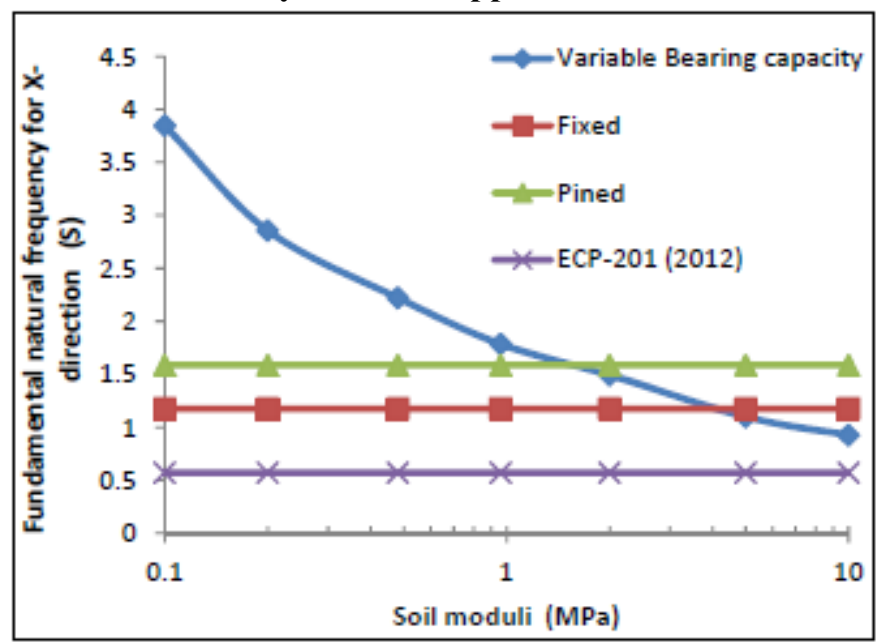

Figure 7: Influence of soil modulus on fundamental natural period of frame system in $\mathrm{X}$-direction 


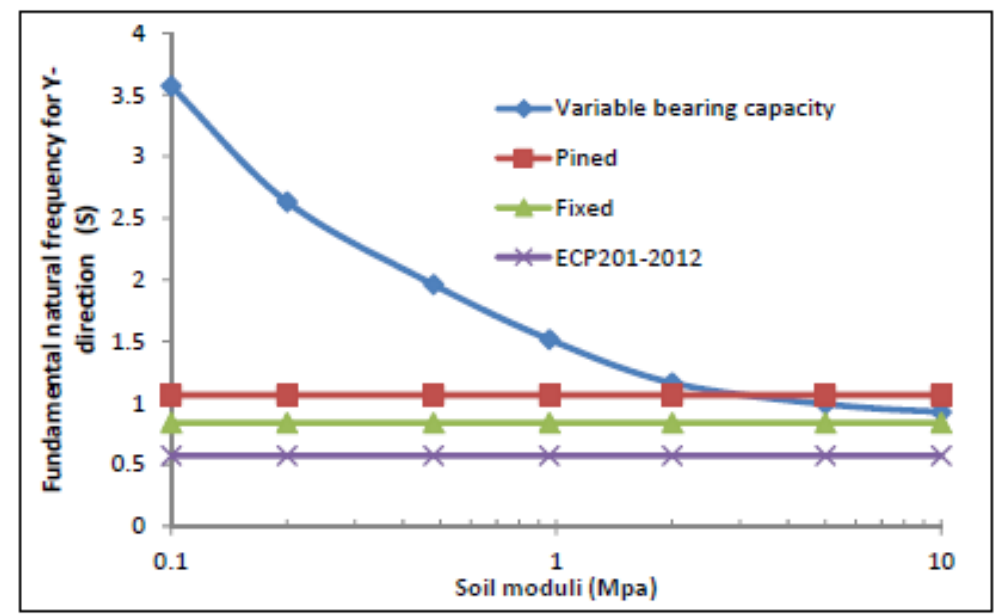

Figure 8: Influence of soil modulus on fundamental natural period of frame system in $\mathrm{Y}$-direction

Hence, a thorough review of the estimation of the natural period of system is important. It should also be noted that most of the soils experience loss in strength and stiffness during shaking, especially, during high magnitude of earthquakes. From structural design point of view, this aspect should be properly taken into account.

Figure 9 shows results of the 3D frame system with maximum seismic base shear forces in X-direction for different idealizations namely fixed base, pinned base, base with soil modulus of $10 \mathrm{MPa}, 5 \mathrm{MPa}, 2 \mathrm{MPa}$, $0.96 \mathrm{MPa}, 0.48 \mathrm{MPa}, 0.20 \mathrm{MPa}$ and $0.10 \mathrm{MPa}$. The base shear is plotted along vertical axis and roof displacement along horizontal axis. It can be seen that, for the case in which the soil modulus is very low $(\mathrm{Q}=1 \mathrm{MPa})$, roof displacement increases linearly with increase in base shear up to around $320 \mathrm{KN}$ and the structure will not take any further load.

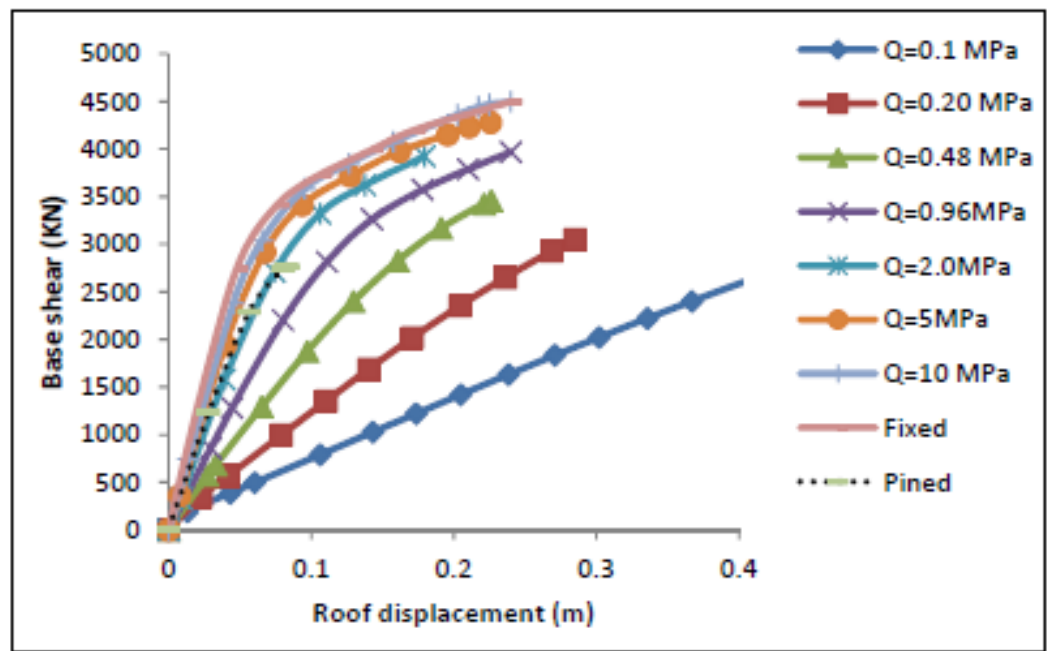

Figure 9: Pushover curves for 3D frame system with seismic force in $\mathrm{X}$ - direction on grounds of varying soil moduli

Figure 10 represents the pushover curves for 3D frame system with seismic force acting in $\mathrm{Y}$ direction. It has similar trend as in the previous case except that the base shear carrying capacity is increased because of higher stiffness to horizontal load in Y direction. Further, very soft soil will not allow much base shear and hinges are within operational range. But failure is due to the failure of base. 


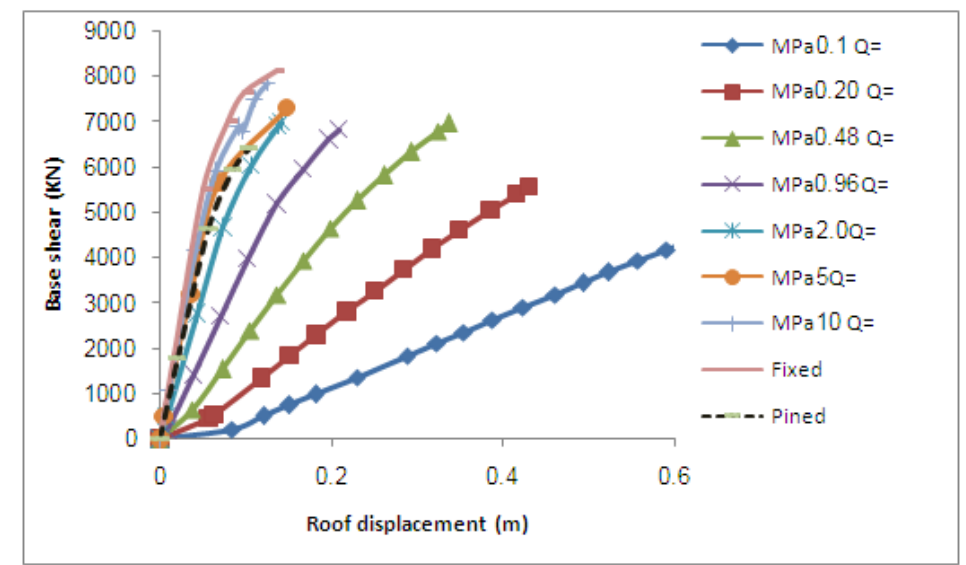

Figure 10: Pushover curves for 3D frame system with seismic force in $\mathrm{Y}$ - direction on grounds of varying soil moduli

The deformed shapes and plastic hinges of the frame indicated in Figure 3 and Figure 4 are presented in Figure 11 and Figure 12 for very soft soil and very hard soil respectively. These two Figures show that the number of hinges and hinges status increase with increasing of base shear for frame resting on hard soil than that resting on soft soil.

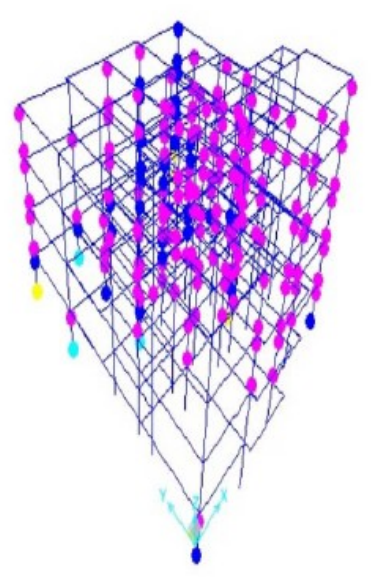

Figure 11a. $\mathrm{X}$-direction

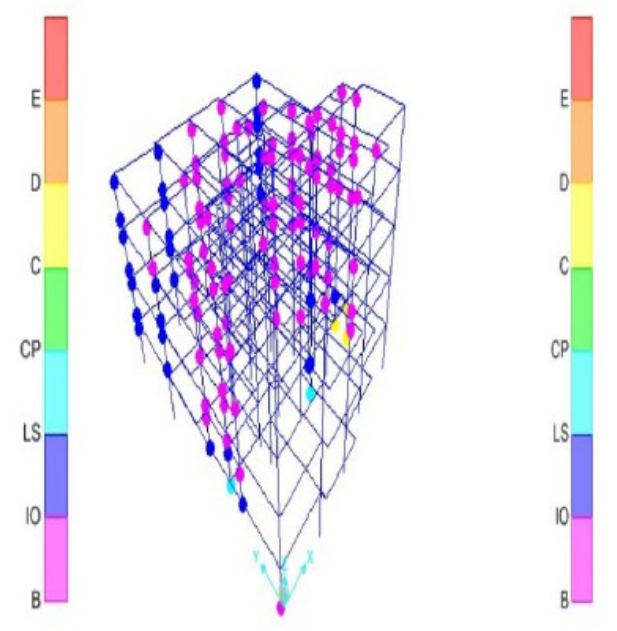

Figure 11b. Y-direction

Figure 11: Deformation and distribution of plastic hinges for very soft soil

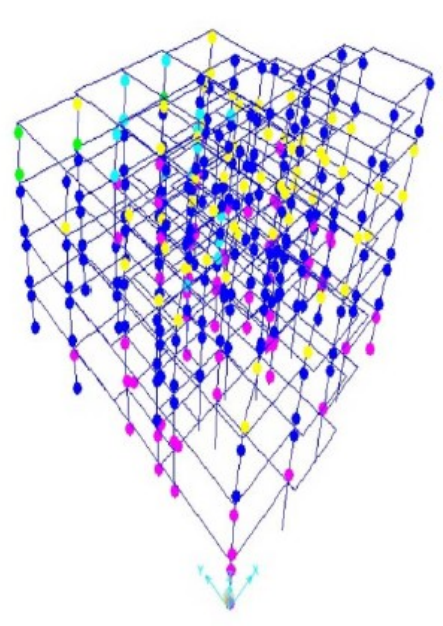

Figure 12a. X-direction

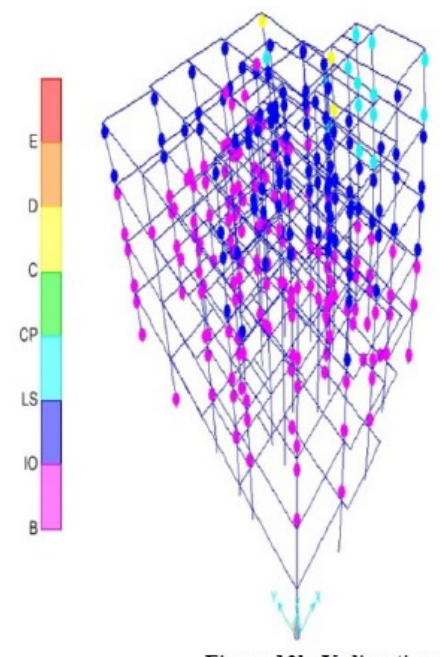

Figure 12b. Y-direction

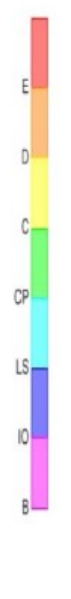

Figure 12: Deformation and distribution of plastic hinges for very hard soil 


\section{Summary and Conclusions}

The present study makes an effort to evaluate the effect of soil-structure interaction on primary dynamic characteristics of low-rise buildings with isolated footing and raft foundation and attempts to provide exhaustive guidelines regarding this issue. Also, the focus of the present paper is to emphasize the need for taking the flexibility of ground into account during seismic design of structures. The following are the major inferences from the present paper:-

A. Natural period of the system increases when the ground becoming softer.

B. Natural period of the system on rigid base coincided very well with that of frame resting on soil of very large stiffness. Further, the performances of the two frames against earthquake loading also matched and were found to be better than frame resting on softer soil. Hence, it is not very important to bother about the seismic performance of structures on firm soil whereas care is necessary for structures resting on soft soil.

C. Natural period computed by empirical equation available in the codalprovisions[3] needs a thorough scrutiny.

D. The study shows that the effect of soil-structure interaction may appreciably alter the lateral natural periods of any structure. This is the primary parameter, which regulates the seismic lateral response of the building frames. Thus, evaluation of this parameter without considering soil-structure interaction may cause serious errors in seismic design.

E. The study shows that the effect of soil-structure interaction on lateral natural period has the same trend even if a raft foundation is provided instead of isolated footings. This is evident from the comparison of the results for two building frames having two types of foundations.

F. The soil structure interaction could lead to effective reduction in the deduced column base shear by increasing empirical natural frequency values by about $20 \%$ as mentioned in ECP201-2012.

G. The pushover method has proved to be a very useful method for studying the effect of soil-structure interaction on seismic assessment of building.

H. It should be noted that for reaching results that are more general, more detailed analyses with variable structural system verying in height, dimensions, vertical structural distributions and different types of foundations should be examined.

\section{References}

[1] Gazetas, G. , "Formulas and Charts for Impedances of Surface and Embedded Foundations", Journal of Geotechnical Engineering, ASCE, vol. 117, No. (9), pp. 1363-1381, 1991.

[2] SAP2000 V15, Integrated Software For Structural Analysis \& Design. Computers \& Structures, Inc., Berkeley, California, USA, 2013.

[3] Mylonakis G. and Gazetas G., "Vertical Vibration and Additional Distress of Grouped Piles in Layered Soil", Soils and Foundations, Japanese Geotechnical Society; Vol. 38, pp.1-14, 1998.

[4] Stewart, JP, GL Fenves, and RB Seed, "Seismic soil-structure interaction in buildings. I: Analytical aspects," J. Geotech. \&Geoenv. Engrg., ASCE, Vol. 125, No. (1), pp. 26-37, 1999.

[5] Stewart, JP, RB Seed, and GL Fenves , "Seismic soil-structure interaction in buildings. II: Empirical findings," J. Geotech. \&Geoenv. Engrg., ASCE, Vol. 125, No. (1), pp. 38-48, 1999.

[6] Mylonakis G. and Gazetas G., "Seismic Soil-Structure Interaction: Beneficial or Detrimental?" Journal of Earthquake Engineering, Vol. 4, pp. 277-301, 2000 .

[7] Boris Jeremi'c, SashiKunnath and Feng Xiong, "Influence of Soil-Structure interaction on Seismic Response of Bridges", International Journal for Engineering Structures, Vol. 26, Issue 3, pp. 391-402, 2004.

[8] Khalil, L. ,Sadek, M. and Shahhrour, I., " Influence of the soil-structure interaction (SSI) on the fundamental frequency of structures", 4th International Conference on Earthquake Geotechnical Engineering, June 25-28,2007.

[9] Gullu, H. and Pala, M. " On the resonance effect by dynamic soil-structure interaction: a revelation study", J. Nat Hazards, Springer Science Business Media Dordrecht, Vol. 72, No. 2, pp 827-847, 2014.

[10] The Egyptian Loading Code, ECP-201, pp. 108-158, 2012.

[11] Desai C.S., Phan H.V. and Perumpral J.V. , "Mechanics of Three-Dimensional Soil-Structure" Interaction. Journal of the Engineering Mechanics Division. Vol. 108, No. (5), pp.731-747, 1982.

[12] Aljanabi A.I.M., FaridB.J.M. and Mohamed A.A.A. , "Interaction of plane frames with elastic foundation having normal and shear moduli of subgrade reactions", Journal of Computers and Structures. Vol. 36, No. (6), pp. 1047-1056, 1990.

[13] Mandal A., Moitra D. and Dutta S.C., "Soil-Structure Interaction on Building Frame: a Small Scale Model Study", International Journal of Structures. Vol. 18, No. (2), pp. 92-108, 1998.

[14] Al-Shamrani M.A. and Al-Mashary F.A., "A Simplified Computation of the Interactive Behavior between Soils and Framed Structures", Journal of King Saud University, Engineering Science, Vol. 16, No. (1), pp. 37-60, 2003.

[15] Bhattacharya, K. , Dutta, S.C. , "Assessing lateral period of building frames incorporating soil-flexibility", Journal of Sound and Vibration, Vol. 269, Issue 3-5, pp. 795-821, 2004.

[16] Thangaraj D. and Ilamparuthi K. , "Parametric Study on the Performance of Raft Foundation with Interaction of Frame",", The Electronic Journal of Geotechnical Engineering, EJGE. Vol. 15, pp. 861-878, 2010.

[17] Agrawal R. and Hora M.S. , "Nonlinear interaction behaviour of plane frame-layered soil system subjected to seismic loading", Structural Engineering and Mechanics. Vol. 41, No. (6), pp. 711-734, 2012.

[18] Chinmayi H.K., Jayalekshmi B.R. ,"Soil-Structure interaction effects on seismic response of a 16 storey RC framed building with shear wall", American Journal of Engineering Research (AJER) Vol. 2, pp.53-58, 2013. 